\title{
Antioxidant pyrrolidine dithiocarbamate prevents defective bradykinin-stimulated calcium accumulation and nitric oxide activity following exposure of endothelial cells to elevated glucose concentration
}

\author{
G. M. Pieper, L. A. Dondlinger \\ Department of Transplant Surgery, Medical College of Wisconsin, Milwaukee, USA
}

\begin{abstract}
Summary Previous studies from our laboratory suggest that reactive oxygen contributes to diminished bradykinin-stimulated calcium accumulation in endothelial cells exposed to elevated glucose concentrations. In this study, we evaluated the efficacy of the antioxidant pyrrolidine dithiocarbamate (PDTC), in preventing defects in intracellular calcium signalling and nitric oxide (NO) activity in endothelial cells exposed to elevated glucose concentration. We show that PDTC prevented the elevated glucose-induced impairment in bradykinin-stimulated calcium accumulation without changing the normal calcium accumulation in response to ionomycin. Furthermore,
\end{abstract}

the impaired cyclic GMP in RFL-6 detector cells (an index of NO activity) generated by bradykinin-stimulation of high glucose-exposed endothelial cells was restored to normal by pretreatment with PDTC. These studies support a role of reactive oxygen in elevated glucose-induced defects in calcium signalling and NO activity by endothelial cells and that antioxidants may be useful in preventing this defect. [Diabetologia (1998) 41: 806-812]

Keywords Pyrrolidine dithiocarbamate, nitric oxide, endothelium, hydroxyl radical, intracellular calcium, diabetes mellitus, hyperglycaemia, antioxidants.
Endothelium-dependent relaxation is impaired in diabetes [1-4]. It is probable that chronic exposure of blood vessels to elevated glucose concentrations contribute to impaired endothelium-dependent relaxation in diabetes mellitus since restoration of glycaemic control by islet [5] or whole pancreas [6] transplantation restores relaxation to normal. This hypothesis is strengthened by studies showing that exposure of normal arteries to elevated glucose concen-

Received: 11 November 1997 and in final revised form: 26 February 1998

Corresponding author: Dr. G. M. Pieper, Department of Transplant Surgery, Medical College of Wisconsin, Froedtert Memorial Lutheran Hospital, 9200 West Wisconsin Avenue, Milwaukee, WI 53226, USA

Abbreviations: PDTC, Pyrrolidine dithiocarbamate; NO, nitric oxide; $\bullet \mathrm{OH}$, hydroxyl radical; $\mathrm{NF}-\varkappa \mathrm{B}$, nuclear factor kappa $\mathrm{B}$; IBMX, isobutyl-1-methylxanthine; HEPES, N-2-hydroxyethylpiperazine- $\mathrm{N}^{\prime}$-2ethanesulphonic acid; SOD, superoxide dismutase. tration in vitro [7-9] or in vivo [10-12] result in defective endothelium-dependent relaxation.

Release of agonist-stimulated NO from the vascular endothelium which contributes to endotheliumdependent relaxation is regulated by increases in intracellular calcium concentration $\left[\mathrm{Ca}^{2+}{ }_{i}\right]$. We have recently shown that exposure of cultured endothelial cells to elevated glucose concentrations (but not elevated mannose or sucrose concentrations) results in decreased bradykinin-stimulated $\left[\mathrm{Ca}^{2+}{ }_{i}\right]$ and NO production [13].

While defective endothelium-dependent relaxation after exposure of intact blood vessels to elevated glucose concentration is believed to be mediated via oxygen-derived free radicals, the role of oxygenderived free radicals contributing to impaired $\mathrm{Ca}^{2+}{ }_{i}$ signalling and NO production in isolated endothelial cells exposed to elevated glucose concentration has yet to be ascertained. In the present study, we evaluated the efficacy of PDTC, an antioxidant and metal chelator $[14,15]$, in preventing glucose-induced defects in $\mathrm{Ca}^{2+}{ }_{\mathrm{i}}$ signalling in bovine aortic endothelial 


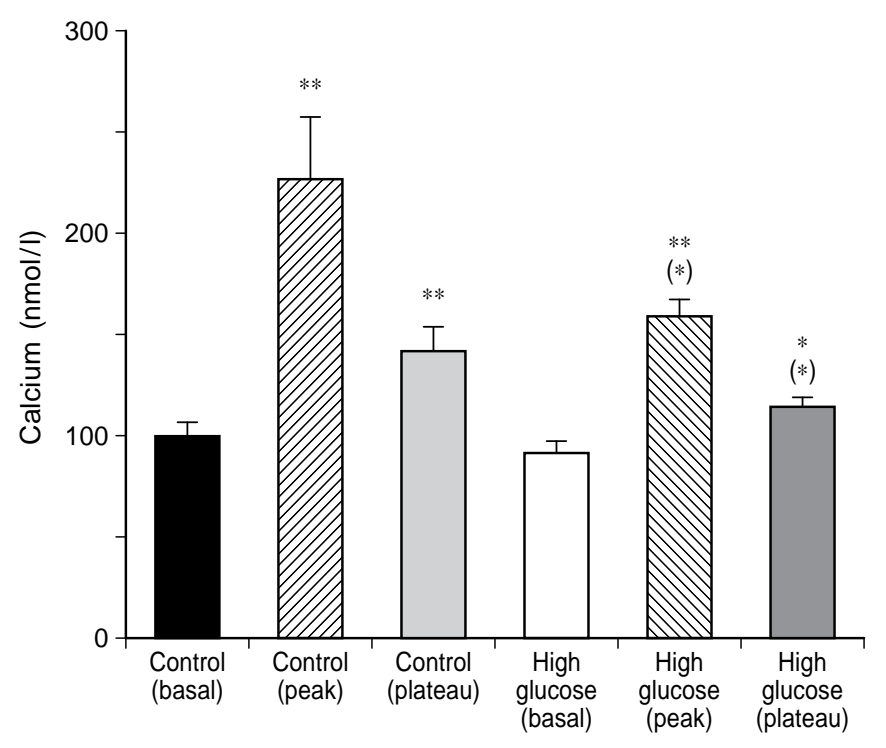

Basal and bradykinin-stimulated

Fig. 1. Effects of previous incubation for $24 \mathrm{~h}$ with high glucose $(35 \mathrm{mmol} / \mathrm{l})$ concentration versus control glucose $(5.5 \mathrm{mmol} / \mathrm{l})$ in media on $\left[\mathrm{Ca}^{2+}{ }_{\mathrm{i}}\right]$ at baseline and at peak and plateau after stimulation of bovine aortic endothelial cells stimulated with $200 \mathrm{nmol} / \mathrm{l}$ bradykinin. Results reflect the mean \pm SEM of $n=7$ paired experiments. $* p<0.05$ and $* * p<0.01$ compared with basal response in the same cells; $(*) p<0.05$ compared with pair-matched response in control cells

cells using fluorescence spectroscopy. In addition, we investigated whether improvements in $\mathrm{Ca}^{2+}{ }_{i}$ signalling by PDTC pretreatment resulted in enhanced NO activity.

\section{Materials and methods}

Bovine aortic endothelial cells (passage no. 2) were obtained from N.I. A. Cell Culture Repository (Coriell Institute for Medical Research, Camden, N.J., USA). Cells were grown in monolayers in MEM (minimum essential media) media supplemented with $10 \%$ fetal calf serum, $1 \%$ glutamine, 100 $\mathrm{U} / \mathrm{ml}$ penicillin, $100 \mu \mathrm{g} / \mathrm{ml}$ streptomycin, $20 \mu \mathrm{g} / \mathrm{ml}$ gentamicin, $8 \mu \mathrm{g} / \mathrm{ml}$ tylosin and $0.25 \mu \mathrm{g} / \mathrm{ml}$ amphotericin in humidified $95 \%$ air and $5 \% \mathrm{CO}_{2}$. Endothelial cells after passages 5-9 were used for these studies.

At $24 \mathrm{~h}$ prior to $\mathrm{Ca}^{2+}{ }_{\mathrm{i}}$ determinations, the culture media was removed and replaced with glutamine-free, serum-free media containing normal glucose concentration (i.e. $5.5 \mathrm{mmol} / \mathrm{l}$ ) or high glucose (i.e. $35 \mathrm{mmol} / \mathrm{l}$ glucose). In pair-matched cultures, cells were preincubated with $50 \mu \mathrm{mol} / 1$ PDTC for $30 \mathrm{~min}$ before and during $24 \mathrm{~h}$ in media containing control or high glucose. Cells were harvested by adding $0.03 \%$ trypsin in Puck's media, centrifuged and re-suspended in N-2-hydroxyethylpiperazine- $\mathrm{N}^{\prime}$-2ethanesulphonic acid (HEPES)-buffer $(\mathrm{pH}$ 7.4) consisting of (in mmol/l): $137 \mathrm{NaCl}, 5.3 \mathrm{KCl}, 1 \mathrm{MgCl}_{2}, 2$ $\mathrm{CaCl}_{2}, 10$ glucose and 10 HEPES.

Endothelial cells were loaded with FURA-2AM (20 $\mu \mathrm{mol}$ final concentration) for $30 \mathrm{~min}$ in the dark, diluted with $10 \times$ volumes of buffer and incubated for $30 \mathrm{~min}$. After loading with indicator, the cells were centrifuged, washed and re-sus-

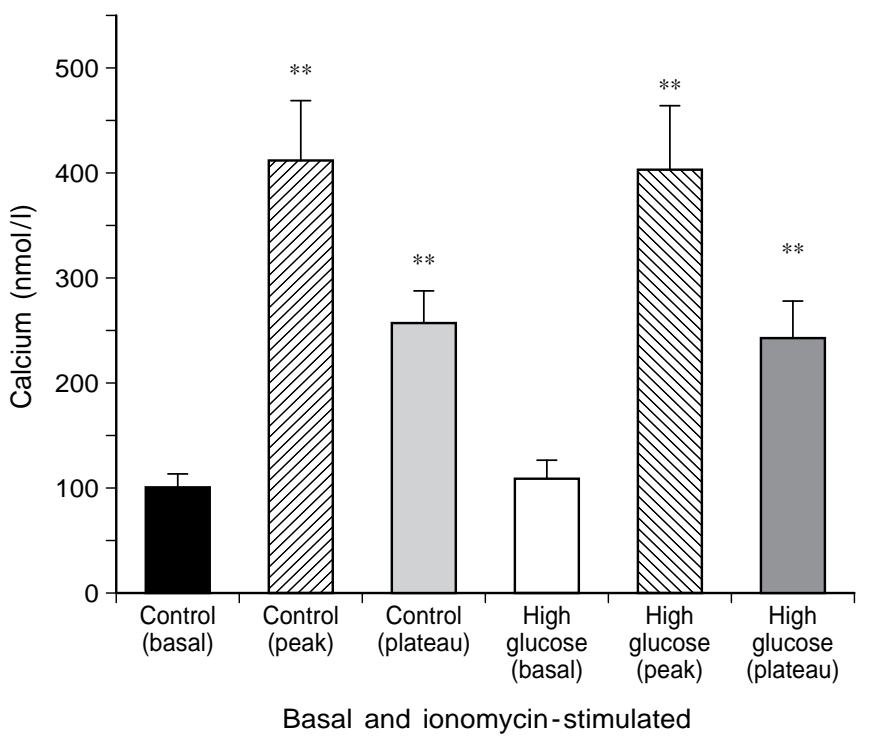

Fig. 2. Exposure to $35 \mathrm{mmol} / \mathrm{l}$ glucose for $24 \mathrm{~h}$ does not alter the peak and plateau $\left[\mathrm{Ca}^{2+}{ }_{\mathrm{i}}\right]$ in endothelial cells stimulated by $190 \mathrm{nmol} / \mathrm{l}$ ionomycin. Results reflect the mean \pm SEM of $n=7$ paired experiments. $* * p<0.01$ compared with $\left[\mathrm{Ca}^{2+}{ }_{\mathrm{i}}\right]$ under basal, unstimulated conditions

pended to $3.2 \times 10^{5}$ cells $/ \mathrm{ml}$ using HEPES-buffered saline $(\mathrm{pH}$ 7.4). $\left[\mathrm{Ca}^{2+}{ }_{\mathrm{i}}\right]$ was determined using a Perkin-Elmer Model LS50 spectrofluorometer. Fluorescence was measured at excitation wavelengths of 333 and $375 \mathrm{~nm}$ and emission wavelength of $510 \mathrm{~nm}$ and corrected for autofluorescence as described in our previous study [13]. $\left[\mathrm{Ca}^{2+}{ }_{\mathrm{i}}\right]$ was determined under resting conditions and after stimulation with $200 \mathrm{nmol} / \mathrm{l}$ bradykinin or $190 \mathrm{nmol} / \mathrm{l}$ ionomycin representing receptor-dependent and receptor-independent agonists for NO release.

Additional studies were performed to evaluate the change in NO production by monolayers of endothelial cells exposed to elevated glucose in the presence or absence of PDTC using the cyclic GMP generated in RFL-6 detector cells [16] and described previously in our laboratory [13]. In addition to the use of detector cells to improve sensitivity and detection of released NO activity, endothelial cells were stimulated with either bradykinin or ionomycin at $1 \mu \mathrm{mol}$. Media (containing $100 \mathrm{U} / \mathrm{ml}$ superoxide dismutase (SOD) and $100 \mu \mathrm{mol}$ IBMX) from basal and agonist-stimulated endothelial cells was transferred after 2 min to RFL- 6 cells in the presence of SOD and IBMX and the reaction terminated using ice cold TCA after 2 min. Using this protocol, we have shown that agonist-stimulated cyclic GMP generation is specific for NO since it is blocked by the NO synthase inhibitor, L-nitroarginine [13].

For each experiment, the $\left[\mathrm{Ca}^{2+}{ }_{\mathrm{i}}\right]$ and cyclic GMP measurements were performed in at least duplicate, repeated on individual days and the results of several days averaged. Data were analysed by analysis of variable (ANOVA) for paired or unpaired observations, where appropriate, with a $p<0.05$ chosen to denote statistical significance.

\section{Results}

Exposure to elevated glucose had no effect on basal $\left[\mathrm{Ca}^{2+}{ }_{\mathrm{i}}\right]$ (Fig. 1). Exposure to elevated glucose concentration produced a decrease in bradykinin-stimulated 

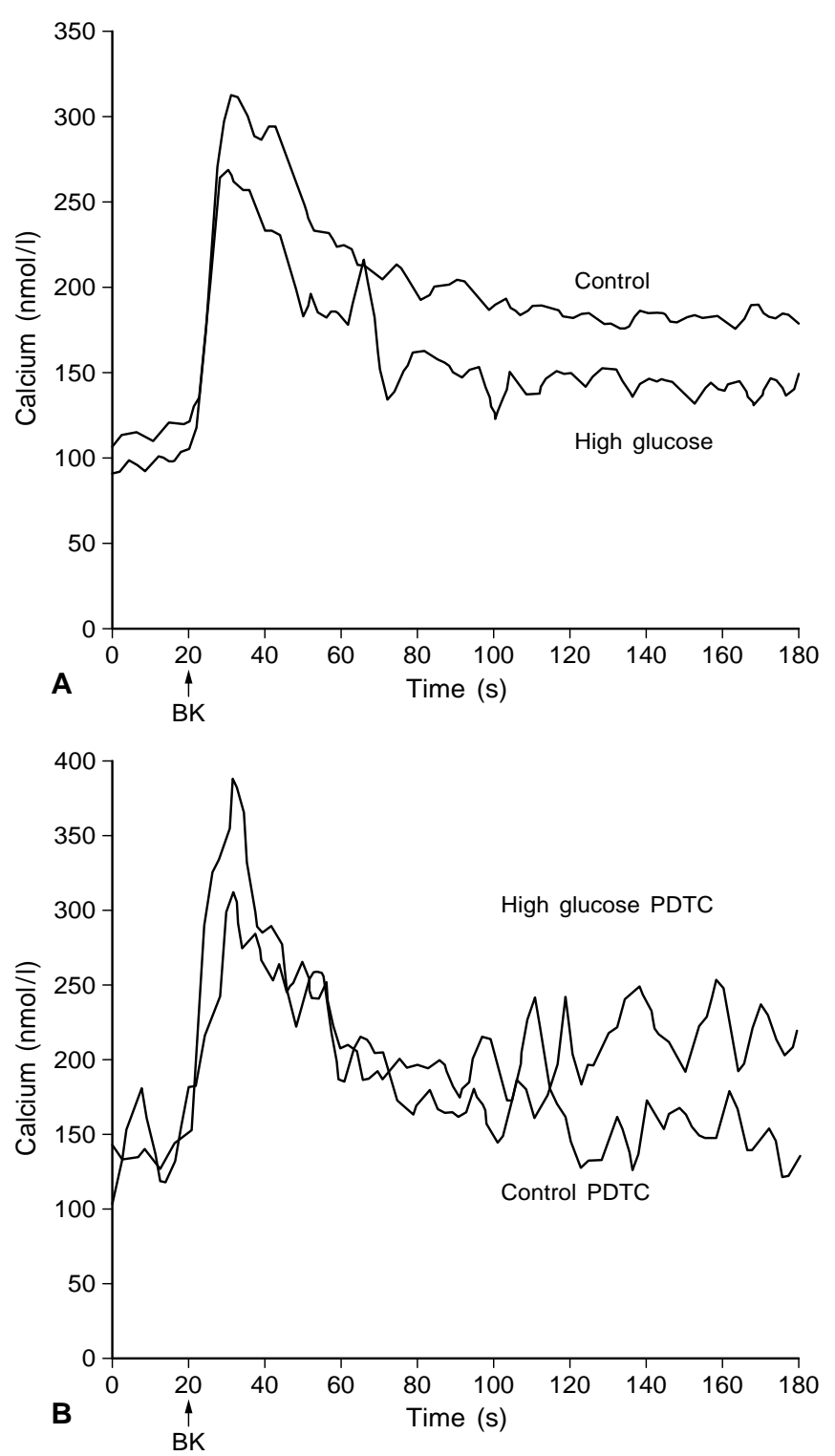

Fig.3. Example showing peak and plateau $\left[\mathrm{Ca}^{2+}{ }_{i}\right]$ in endothelial cells stimulated by bradykinin but exposed previously for $24 \mathrm{~h}$ in the presence of either $5.5 \mathrm{mmol} / \mathrm{l}$ glucose (control) or $35 \mathrm{mmol} / \mathrm{l}$ glucose (high glucose) in the absence (panel A) or presence (panel B) of the antioxidant, PTDC $(50 \mu \mathrm{mol} / \mathrm{l})$

$\left[\mathrm{Ca}^{2+}{ }_{\mathrm{i}}\right]$ assessed at the peak response $(1 \mathrm{~min})$ or at the plateau phase ( $3 \mathrm{~min})$ following bradykinin. In contrast, ionomycin-stimulated $\left[\mathrm{Ca}^{2+}{ }_{i}\right]$ at 1 and $3 \mathrm{~min}$ post-stimulation was unaltered by elevated glucose exposure (Fig. 2). Pretreatment with PDTC prevented the attenuated bradykinin-stimulated $\mathrm{Ca}^{2+}{ }_{i}$ at both peak and plateau phases in cells exposed to elevated glucose concentration (example shown in Fig. 3) while having no effect on cells exposed to normal media glucose concentration or on basal $\left[\mathrm{Ca}^{2+}{ }_{\mathrm{i}}\right]$ in either group (Fig. 4). In cells exposed to elevated glucose concentration, pretreatment with PDTC did not alter the peak or plateau $\left[\mathrm{Ca}^{2+}{ }_{i}\right]$ in response to ionomycin (Fig. 5).

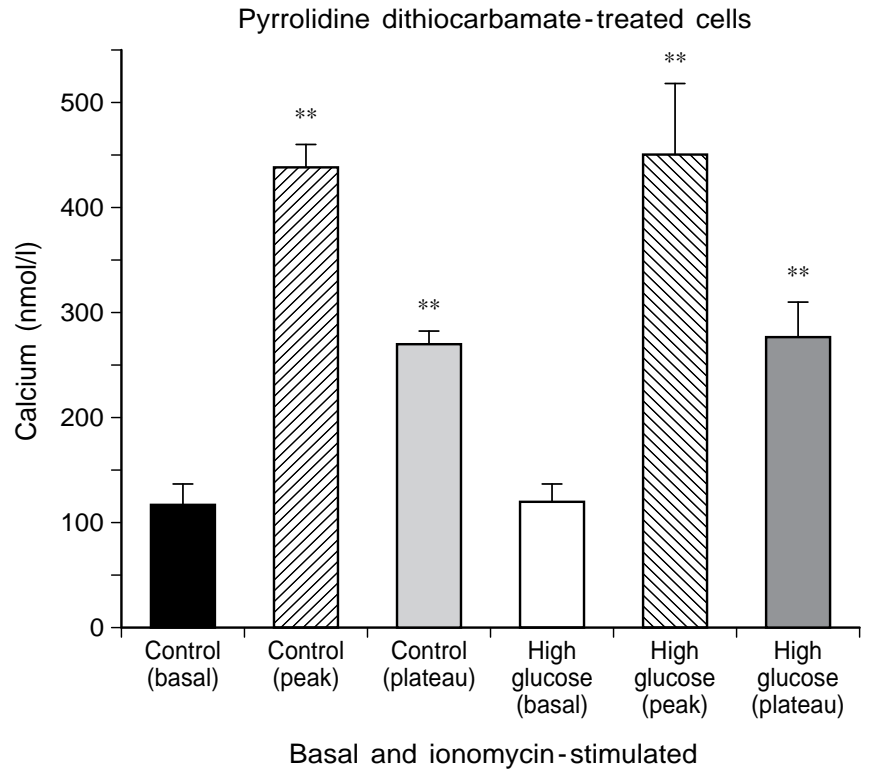

Fig. 4. Pair-matched experiments showing the lack of attenuated bradykinin-stimulated $\left[\mathrm{Ca}^{2+}{ }_{i}\right]$ during peak and plateau phases in endothelial cells exposed previously for $24 \mathrm{~h}$ with $35 \mathrm{mmol} / \mathrm{l}$ vs $5.5 \mathrm{mmol} / \mathrm{l}$ glucose but pretreated with the antioxidant, PDTC $(50 \mu \mathrm{mol} / \mathrm{l})$. Results reflect the mean \pm SEM of $n=10$ paired experiments. ** $p<0.01$ compared with $\left[\mathrm{Ca}^{2+}{ }_{\mathrm{i}}\right]$ under basal, unstimulated conditions

Previous exposure to elevated glucose conditions produced no significant change $(p>0.05)$ in the cyclic GMP generated within RFL-6 detector cells in endothelial cells stimulated with ionomycin (i. e. $5.5 \mathrm{mmol} / \mathrm{l}$ glucose: $4.92 \pm 0.34 \mathrm{pmol} / \mathrm{mg}$ protein; $35 \mathrm{mmol} / \mathrm{l} \mathrm{glu}-$ cose: $5.60 \pm 0.47 \mathrm{pmol} / \mathrm{mg}$ protein, $n=7$ paired experiments). In contrast, cyclic GMP generation was diminished by bradykinin-stimulated endothelial cells exposed to elevated glucose concentration (Fig.6). Furthermore, treatment with PDTC normalized the cyclic GMP production elicited by bradykinin-stimulated endothelial cells exposed to elevated glucose concentration.

\section{Discussion}

Chronic treatment of experimental diabetic animals with antioxidants such as dimethylthiourea [17] or vitamin E [18] has been shown to prevent the impairment of endothelium-dependent relaxation. The observation that scavengers of reactive oxygen can also prevent the impairment of endothelium-dependent relaxation initiated by acute exposure of normal arteries to elevated glucose concentrations [7-10] suggests that reactive oxygen generated under high glucose conditions may contribute to the etiology of defective relaxation.

Indeed, a significant increase in reactive oxygen production has been demonstrated previously during 


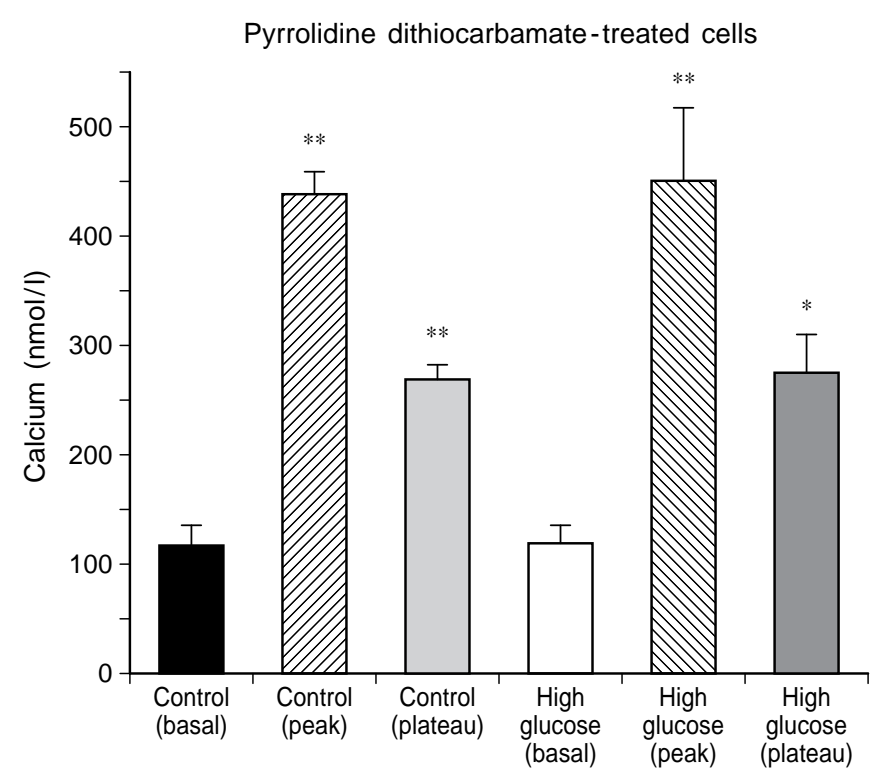

Basal and ionomycin-stimulated

Fig.5. Pretreatment with $50 \mu \mathrm{mol} / \mathrm{l}$ PDTC does not alter the ionomycin-stimulated $\left[\mathrm{Ca}^{2+}{ }_{\mathrm{i}}\right]$ in endothelial cells exposed for $24 \mathrm{~h}$ to $35 \mathrm{mmol} / \mathrm{l}$ glucose vs $5.5 \mathrm{mmol} / \mathrm{l}$ glucose. Results reflect the mean \pm SEM of $n=7$ paired experiments. ** $p<0.01 \mathrm{com}-$ pared with $\left[\mathrm{Ca}^{2+}{ }_{\mathrm{i}}\right]$ under basal, unstimulated conditions

the actual exposure period of bovine endothelial cells to elevated glucose concentration using fluorescence spectroscopic techniques [13, 19]. In other studies, prior exposure to elevated glucose concentration and subsequent removal also produced a latent increase in the endogenous rate of superoxide radical release by murine or porcine endothelial cells as determined by the ferricytochrome $\mathrm{C}$ technique [20, 21]. Taken together, these observations suggest two separate effects of high glucose concentrations on reactive oxygen production from endothelial cells: a) direct stimulation of reactive oxygen co-incidental with glucose incubations and; b) indirect modification in the intrinsic rate of spontaneous reactive oxygen production following prolonged exposure to elevated glucose.

In our study, we found that pretreatment with the antioxidant, PDTC, prevented the reduction in both bradykinin-stimulated $\mathrm{Ca}^{2+}{ }_{\mathrm{i}}$ and $\mathrm{NO}$ activity as a result of exposure to elevated glucose concentration. This effect could not be explained by a generalized improvement in $\mathrm{Ca}^{2+}{ }_{\mathrm{i}}$ signalling since the response to the receptor-independent agonist, ionomycin, was not enhanced by PDTC treatment. Furthermore, the restoration of bradykinin-stimulated $\left[\mathrm{Ca}^{2+}{ }_{i}\right]$ was associated with an improvement in $\mathrm{NO}$ activity as judged by the improved cyclic GMP generated in RFL- 6 detector cells. This is consistent with a role of $\mathrm{Ca}^{2+}{ }_{i}$ signalling for NO release.

Previous studies have shown that elevated glucose decreases agonist-stimulated $\mathrm{Ca}^{2+}{ }_{\mathrm{i}}$ production or $\mathrm{NO}$

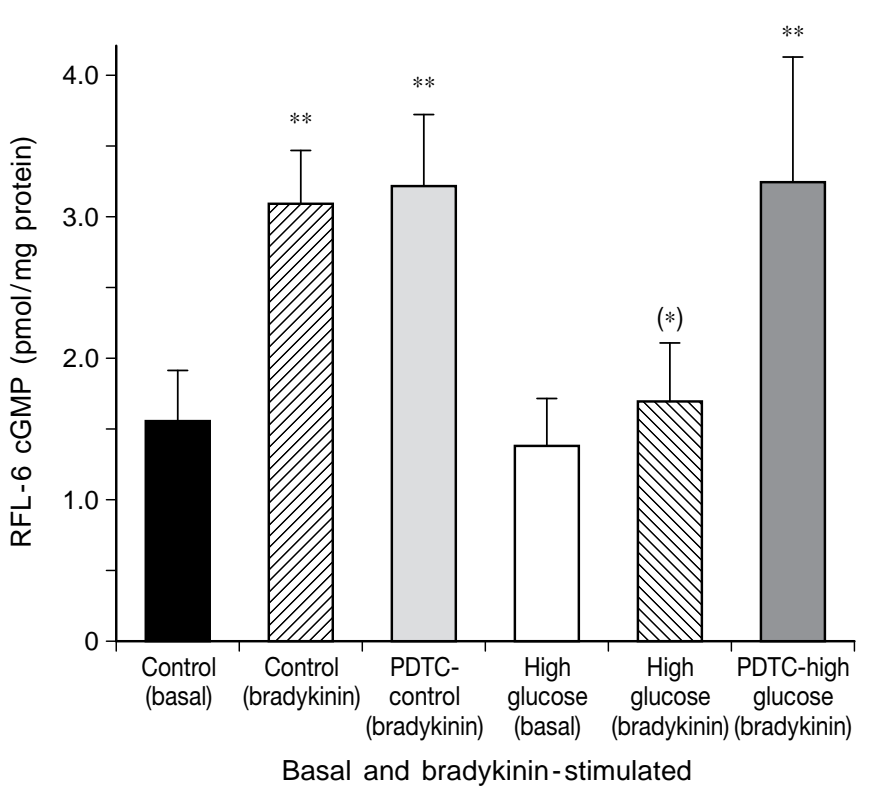

Fig. 6. Exposure to $35 \mathrm{mmol} / \mathrm{l}$ glucose for $24 \mathrm{~h}$ impairs and pretreatment with $50 \mu \mathrm{mol} / \mathrm{l}$ PDTC reverses bradykinin-stimulated nitric oxide activity arising from endothelial cells as assessed by cGMP generation in RFL-6 detector cells. Results reflect the mean \pm SEM. Untreated cells $(n=7)$; treated cells $(n=5)$. ** $p<0.01$ compared with cGMP generated under the corresponding basal, unstimulated conditions; $(*) p<0.05$ compared with bradykinin-stimulated response in control cells

activity or both in porcine $[22,23]$ and rat endothelial cells [24]. Furthermore, previous exposure of endothelial cells to exogenous reactive oxygen (e.g. peroxides) also diminishes receptor-dependent $\mathrm{Ca}^{2+}{ }_{i}$ signalling [25-27]. The finding that both oxidants [28] and high glucose concentrations $[9,11]$ selectively impair receptor-mediated endothelium-dependent relaxation of normal blood vessels, taken together with the findings in isolated endothelial cell preparations, suggests a defect in receptor coupling of $\mathrm{Ca}^{2+}{ }_{\mathrm{i}}$ signalling to NO synthesis and that this is not due to a generalized defect in endothelial cell function.

The precise location of this defect is not known. Our previous work using the G-protein activators, $\mathrm{NaF}[13]$ and mastoparan (unpublished observations) in endothelial cells suggests that there is also no direct intrinsic defect in G-protein initiated $\mathrm{Ca}^{2+}{ }_{\mathrm{i}}$ increases and that a site proximal to G-protein activation may be important in this differential effect of elevated glucose. According to previous studies using differing endothelial cell types [29-31], ionomycin stimulates intracellular $\mathrm{Ca}^{2+}{ }_{\mathrm{i}}$ accumulation by release from intracellular stores followed by entry from extracellular sources. This entry is believed to occur via bradykinin-like entry pathways but to be elicited via a receptor-independent mechanism. Accordingly, our results suggest the possibility that the glucose-induced defect arises from altered $\mathrm{Ca}^{2+}$ release while indirectly impacting on extracellular $\mathrm{Ca}^{2+}$ entry. Since 
the plateau phase of ionomycin was not altered by glucose, this suggests a defect that is unique to receptor-mediated coupling of intracellular $\mathrm{Ca}^{2+}$ release and extracellular $\mathrm{Ca}^{2+}$ entry.

As opposed to the findings of defective $\mathrm{Ca}^{2+}{ }_{\mathrm{i}}$ signalling and $\mathrm{NO}$ activity by elevated glucose exposure of bovine (this study), porcine [22, 23] and rat [24] endothelial cells, other investigators have shown that elevated glucose exposure enhanced basal or agoniststimulated $\mathrm{Ca}^{2+}{ }_{\mathrm{i}}$ signalling in porcine [21] and human umbilical vein endothelial cells [32]. These discrepancies may arise from variances in culturing conditions and media, type of endothelial cells, glucose concentration and exposure time, and/or the conditions of measurement of $\mathrm{Ca}^{2+}{ }_{\mathrm{i}}$ and NO/cyclic GMP. As to the $\mathrm{Ca}^{2+}{ }_{i}$ measurements, it is interesting to note that in some studies $[21,29]$ the actual $\mathrm{Ca}^{2+}{ }_{\mathrm{i}}$ measurements appear to have been conducted under substrate-free conditions (i.e. without any glucose in the media). Also, in contrast to all previous studies in this area, our studies evaluated NO production using RFL-6 detector cells rather than detection of cyclic GMP generated within the endothelial cell.

We used this RFL-6 detector system in order to negate any potential influences of variability in endogenous guanylate cyclase within endothelial cells and to obtain a more true measure of the bioactive NO released by the endothelium under these conditions. The provision of extracellular SOD is designed to inhibit interaction of superoxide anion radicals released from endothelial cells with NO released from endothelial cells. Without SOD this interaction could have produced diminished bioactive NO in the media and, thus, NO dectected by the RFL-6 cells. This design does not eliminate the possibility that intracellularly generated superoxide might interact with intracellularly generated NO especially after exposure to high-glucose resulting in diminished bioactive NO. It is possible that PDTC returns NO production to normal by preventing changes induced by glucose exposure in intrinsic superoxide generation.

It is interesting that antioxidants including the metal-chelator, desferal, inhibited the enhanced $\mathrm{Ca}^{2+}{ }_{\mathrm{i}}$ signalling and NO activity subsequent to glucose exposure of porcine endothelial cells [21, 33]. Despite these opposing observations of the beneficial effects of antioxidants on enhanced NO activity, no other laboratory has evaluated whether antioxidants can prevent glucose-induced impairment in $\mathrm{Ca}^{2+}{ }_{i}$ signalling and NO activity from isolated endothelial cells. Thus, this study together with our previous study [13] provides important new information regarding the efficacy of antioxidants in preventing glucose-induced signal transduction defects. It also provides the first known application and efficacy of the antioxidant, PDTC, under conditions of elevated glucose concentration.
We concluded previously that intracellular generation of the hydroxyl radical $(\bullet \mathrm{OH})$ was probably the molecular species responsible for the attenuation in bradykinin-stimulated $\mathrm{Ca}^{2+}{ }_{i}$ and $\mathrm{NO}$ production by exposure of endothelial cells to elevated glucose concentration, since these defects were prevented by dimethylthiourea (an intracellular $\bullet \mathrm{OH}$ scavenger) but not by either mannitol (an extracellular $\bullet \mathrm{OH}$ scavenger), SOD (an extracellular enzyme which converts superoxide anion to $\mathrm{H}_{2} \mathrm{O}_{2}$ ) or catalase (an extracellular enzyme which detoxifies $\mathrm{H}_{2} \mathrm{O}_{2}$ ). Our findings support and extend the conclusion that the -OH plays a significant role in endothelial cell dysfunction produced by elevated glucose concentration based upon the understanding that the dithiocarbamate PDTC (unlike dimethylthiourea) is both a metal chelator and an $\bullet \mathrm{OH}$ scavenger $[14,15]$. Thus, the present study provides new information that metal ion-catalysed $\bullet \mathrm{OH}$ plays a role in defective $\mathrm{Ca}^{2+}{ }_{\mathrm{i}}$ signalling and $\mathrm{NO}$ release in endothelial cells exposed to high glucose conditions. This conclusion is consistent with our recent study showing that chronic treatment in vivo with a conjugated form of deferoxamine prevented the impaired endothelium-dependent relaxation in diabetic rats [34]. Collectively, these findings support the hypothesis that elevated glucose conditions generate reactive oxygen via a metal-catalysed process [35].

In addition, we suggest for various reasons that PDTC is probably acting via an intracellular process to prevent glucose-induced defects. First, we indicated previously a requirement for intracellular glucose action since no defects in $\left[\mathrm{Ca}^{2+}{ }_{i}\right]$ were seen if glucose uptake was inhibited using cytochalasin B [13]. Second, PDTC has been used frequently as a classical inhibitor of cytokine-induced activation of the transcription factor, nuclear factor kappa B (NF- $x \mathrm{~B})$. This activation requires an intracellular signal which is believed to be mediated by reactive oxygen in particular $\bullet \mathrm{OH}$ [15]. NF- $x \mathrm{~B}$ activation may play a key role in etiology of endothelial cell dysfunction in diabetes since it binds to the promoter region of several genes including those which encode various adhesion proteins.

Recent studies have shown that glycated albumin produced by incubation of albumin with elevated glucose concentrations produces $\mathrm{NF}-x \mathrm{~B}$ activation in endothelial cells [36]. Independent of this, we have demonstrated recently that oxidative stress produced by elevations in glucose concentration per se may also be a stimulus for NF- $x \mathrm{~B}$ activation since glucose produced a time-dependent and concentration-dependent increase in NF- $x \mathrm{~B}$ activation in endothelial cells [37]. Consistent with the present study, we have observed that NF- $x \mathrm{~B}$ activation occurs as early as a $2 \mathrm{~h}$ after exposure to $35 \mathrm{mmol} / \mathrm{l}$ glucose and that this activation was prevented completely by incubation with PDTC (unpublished observations). Since the ac- 
tivation of $\mathrm{NF}-x \mathrm{~B}$ is an intracellular event, the ability of PDTC to block glucose-induced NF- $x \mathrm{~B}$ expression implies that PDTC can act via an intracellular mechanism. Taken together with the present study, these findings indicate that PDTC may be effective in interrupting a variety of biological processes activated by increases in glucose concentration which could impact on endothelial cell function in hyperglycaemic states.

In summary, our results suggest that the antioxidant, PDTC, was effective in preventing glucose-induced defects in $\mathrm{Ca}^{2+}{ }_{\mathrm{i}}$ and NO production by endothelial cells. These studies support the notion that antioxidants may be effective therapeutic interventions to prevent defects in endothelial cell function associated with hyperglycaemic states such as diabetes mellitus.

Acknowledgements. This work was supported by grant number HL47072 from the National Institutes of Health, Heart and Lung Institute, USA.

\section{References}

1. Pieper GM, Gross GJ (1991) Endothelial dysfunction in diabetes. In: Rubanyi GM (ed) Cardiovascular significance of endothelium-derived vasoactive factors. Futura Publishing, Mount Kisco, N. Y., pp 223-249

2. Cohen RA (1993) Dysfunction of vascular endothelium in diabetes mellitus. Circulation 87 [suppl V]:V67-V76

3. Kamata K, Miyata N, Abiru T, Kasuya K (1992) Functional changes in vascular smooth muscle and endothelium of arteries during diabetes mellitus. Life Sci 50: 1379-1387

4. Poston L, Taylor PD (1995) Endothelium-mediated vascular function in insulin-dependent diabetes mellitus. Clin Sci (colch) 88: 245-255

5. Pieper GM, Jordan M, Adams MB, Roza AM (1995) Syngeneic pancreatic islet transplantation reverses endothelial dysfunction in experimental diabetes. Diabetes 44: 1106-1113

6. Pieper GM, Adams MB, Roza AM (1998) Pancreas transplantation reverses endothelial dysfunction in experimental diabetes mellitus. Surgery 123: 89-95

7. Tesfamariam B, Cohen RA (1992) Free radicals mediate endothelial cell dysfunction caused by elevated glucose. Am J Physiol 263 (Heart Circ Physiol 32):H321-H326

8. Taylor PD, Poston L (1994) The effect of hyperglycaemia on function of rat isolated mesenteric resistance artery. $\mathrm{Br}$ J Pharmacol 113: 801-808

9. Dorigo P, Fraccarollo D, Santostasi G, Maragno I (1997) Impairment of endothelium-dependent but not of endothelium-independent dilatation in guinea-pig aorta rings incubated in the presence of elevated glucose. Brit J Pharmacol 121: 972-976

10. Bohlen HG, Lash JM (1993) Topical hyperglycemia rapidly suppresses EDRF-mediated vasodilation of normal rat arterioles. Am J Physiol 265 (Heart Circ Physiol 34):H219-H225

11. Pieper GM, Meier DA, Hager SR (1995) Endothelial dysfunction in a model of hyperglycemia and hyperinsulinemia. Am J Physiol 269 (Heart Circ Physiol 38): H845-H850
12. Mayhan WG, Patel KP (1995) Acute effects of glucose on reactivity of cerebral microcirculation: role of activation of protein kinase C. Am J Physiol 269 (Heart Circ Physiol 38):H1297-H1302

13. Pieper GM, Dondlinger LA (1997) Glucose elevations alter bradykinin-stimulated intracellular calcium accumulation in cultured endothelial cells. Cardiovasc Res 34: 169-178

14. Sunderman FW, Paynter OE, George RB (1967) The effects of protracted administration of the chelating agent sodium diethyldithiocarbamate (dithiocarb). Am J Med Sci 254: 24-34

15. Schreck R, Meier B, Männel DN, Dröge W, Baeuerle PA (1992) Dithiocarbamates as potent inhibitors of nuclear factor $x \mathrm{~B}$ activation in intact cells. J Exp Med 175: $1181-1194$

16. Ishii K, Sheng H, Warner TD, Forstermann U, Murad F (1991) A simple and sensitive bioassay method for detection of EDRF with RFL-6 rat lung fibroblasts. Am J Physiol 261 (Heart Circ Physiol 30):H598-H603

17. Pieper GM, Siebeneich W, Roza AM, Jordan M, Adams MB (1996) Chronic treatment in vivo with dimethylthiourea, a hydroxyl radical scavenger, prevents diabetes-induced endothelial dysfunction. J Cardiovasc Pharmacol 28: 741-745

18. Keegan A, Walbank H, Cotter MA, Cameron NE (1995) Chronic vitamin $\mathrm{E}$ treatment prevents defective endothelium-dependent relaxation in diabetic rat aorta. Diabetologia 38: 1475-1478

19. Giardino I, Edelstein D, Brownlee M (1996) BCL-2 expression or antioxidants prevent hyperglycemia-induced formation of intracellular advanced glycation endproducts in bovine endothelial cells. J Clin Invest 97: 1422-1428

20. Mazière C, Auclair M, Rose-Robert F, Leflon P, Mazière JC (1995) Glucose-enriched medium enhances cell-mediated low density lipoprotein peroxidation. FEBS Lett 363: 277-279

21. Graier WF, Simecek S, Kukovetz WR, Kostner GM (1996) High D-glucose-induced changes in endothelial $\mathrm{Ca}^{2+}$ EDRF signaling are due to generation of superoxide anions. Diabetes 45: 1386-1395

22. Salameh A, Dhein S (1988) Influence of chronic exposure to high concentrations of D-glucose and long-term $\beta$-blocker treatment on intracellular calcium concentrations of porcine endothelial cells. Diabetes 47: 407-413

23. Weisbrod RM, Brown ML, Cohen RA (1993) Effect of elevated glucose on cyclic GMP and eicosanoids produced by porcine aortic endothelium. Arterioscler Thromb Vasc Biol 13: 915-923

24. Magill SB, Dananberg J (1996) Effects of hyperglycemia on vascular endothelium nitric oxide metabolism. In: Sowers JR (ed) Contemporary endocrinology: endocrinology of the vasculature. Humana Press Inc., Totown, N.J., pp145-156

25. Vercellotti GM, Severson SP, Duane P, Moldow CF (1991) Hydrogen peroxide alters signal transduction in human endothelial cells. J Lab Clin Med 117: 15-24

26. Natarajan V (1994) Oxidants and signal transduction in vascular endothelium. J Lab Clin Med 125: 26-37

27. Schilling WP, Elliott SJ (1992) $\mathrm{Ca}^{2+}$ signaling mechanisms of vascular endothelial cells and their role in oxidant-induced endothelial cell dysfunction. Am J Physiol 262 (Heart Circ Physiol 31):H1617-H1630

28. Pieper GM, Gross GJ (1989) Selective impairment of endothelium-dependent relaxation by oxygen-derived free radicals: distinction between receptor versus nonreceptor mediators. Blood Vessels 26: 44-47 
29. Morgan AJ, Jabob R (1994) Ionomycin enhances $\mathrm{Ca}^{2+}$ influx by stimulating store-regulated cation entry and not by a direct action at the plasma membrane. Biochem J 300: $665-672$

30. Graier WF, Simecek S, Sturek M (1995) Cytochrome P450 mono-oxygenase-regulated signalling of $\mathrm{Ca}^{2+}$ entry in human and bovine endothelial cells. J Physiol (Lond) 482: 259-274

31. Encabo A, Romanin C, Birke FW, Kukovetz WR, Groschner K (1996) Inhibition of a store-operated $\mathrm{Ca}^{2+}$ entry pathway in human endothelial cells by the isoquinoline derivative LOE908. Br J Pharmacol 119: 702-706

32. Sobrevia L, Nadal A, Yudilevich DL, Mann GE (1996) Activation of L-arginine transport (system $\mathrm{y}^{+}$) and nitric oxide synthase by elevated glucose and insulin in human endothelial cells. J Physiol 490: 775-781

33. Graier WF, Simecek S, Hoebel BG, Wascher TC, Dittrich P, Kostner GM (1997) Antioxidants prevent high-D-glu- cose-enhanced endothelial $\mathrm{Ca}^{2+} / \mathrm{cGMP}$ response by scavenging superoxide anions. Eur J Pharmacol 322: 113-122

34. Pieper GM, Siebeneich W (1997) Diabetes-induced endothelial dysfunction is prevented by chronic treatment with the modified iron chelator, hydroxyethyl starch conjugated-deferoxamine. J Cardiovasc Pharmacol 30: 734-738

35. Wolff SP, Dean RT (1987) Glucose autooxidation and protein modification. Biochem J 245: 243-250

36. Bierhaus A, Chevion S, Chevion M et al. (1997) Advanced glycation end product-induced activation of NF- $x \mathrm{~B}$ is suppressed by $\alpha$-lipoic acid in cultured endothelial cells. Diabetes 46: 1481-1490

37. Pieper GM, ul-Haq R (1997) Activation of nuclear factor kappa B in endothelial cells by increasing extracellular glucose concentration: prevention by calphostin C. J Cardiovasc Pharmacol 30: 528-532 